\title{
HUMAM IMMUNODEFICIENCY VIRUS PADA KOMUNITAS GAY DI KAWASAN MARINA PLAZA KOTA MANADO
}

\author{
Jasman $^{\text {a) }}$, Dismo Katiandagho ${ }^{\text {b) }}$, Moningka Dely Natalia ${ }^{\text {c) }}$, Ronny Muntu ${ }^{\text {d) }}$ \\ ${ }^{a, b, c)}$ Jurusan Kesehatan Lingkungan Poltekkes Kemenkes Manado, Indonesia \\ d) Jurusan Kesehatan Lingkungan Poltekkes Kemenkes Makassar, Indonesia \\ E-mail :jasman067@gmail.com,ronnymuntu@gmail.com
}

\begin{abstract}
Human Immunodeficiency Virus (HIV) is a virus that causes Aquired Immunodeficiency Syndrome (AIDS) by attacking white blood cells, namely CD4 cells (Cluster of Differentiation 4) that can damage the human immune system. Without the immune system, a person is easily attacked by various diseases. The number of HIV / AIDS sufferers according to data from the Tikala Baru Health Center VCT in 2018 totaled 62 people. The aim of this study is to identify HIV in the Gay Community in the Marina Plaza Area of Manado City.

The method used in this study is the Immunocromatography Test using One Step Anti-HIV. Sampling was carried out in the Marina Plaza Area and immediately examined at the sampling location. The population in this study is the entire Gay Community in the Marina Plaza Area of Manado City with a total population sampling method. This type of research is descriptive, research results are presented in tabular form and narrated.

Based on research conducted, it can be concluded that, of the 85 respondents examined there were 1 positive respondent and 84 negative respondents. It is recommended for members of the gay community who are infected with HIV to take ARV (Anti Retroviral) drugs regularly. For gay community members who have not been infected with HIV in order to prevent transmission by using a condom during sex or leaving deviant sexual behavior.
\end{abstract}

Key Word : AIDS, HIV, Gay

\begin{abstract}
ABSTRAK
Human Immunodeficiency Virus (HIV) merupakan virus penyebab penyakit Aquired Immunodeficiency Syndrom (AIDS) dengan cara menyerang sel darah putih yaitu sel CD4 (Cluster Of Differentiation 4) yang dapat merusak sistem kekebalan tubuh manusia. Tanpa sistem kekebalan maka seseorang dengan mudah diserang berbagai penyakit. Jumlah penderita HIV/AIDS menurut data dari VCT Puskesmas Tikala Baru pada tahun 2018 berjumlah 62 orang. Tujuan dari penelitian ini adalah untuk mengindentifikasi HIV pada Komunitas Gay di Kawasan Marina Plaza Kota Manado.

Metode yang digunakan dalam penelitian ini adalah Immunocromatography Test menggunakan One Step Anti-HIV. Pengambilan sampel dilaksanakan di Kawasan Marina Plaza dan langsung diperiksa ditempat pengambilan sampel. Populasi dalam penelitian ini adalah seluruh Komunitas Gay di Kawasan Marina Plaza Kota Manado dengan metode pengambilan sampel total populasi. Jenis penelitian yang digunakan adalah deskriptif, hasil penelitian disajikan dalam bentuk tabel dan di narasikan.

Berdasarkan penelitian yang dilakukan, maka dapat disimpulkan bahwa, dari 85 responden yang diperiksa terdapat 1 responden yang positif dan 84 responden yang negatif. Disarankan bagi anggota komunitas gay yang terinfeksi HIV agar mengkonsumsi obat ARV (Anti Retroviral) secar rutin. Bagi anggota komunitas gay yang belum terinfeksi HIV agar dapat mencegah penularan dengan cara menggunakan kondom pada saat melakukan hubungan seks atau meninggalkan perilaku seksual yang menyimpang.
\end{abstract}

Kata Kunci : AIDS, HIV, Komunitas Gay

\section{PENDAHULUAN}

Jumlah penderita HIV/AIDS di dunia sampai pada akhir tahun 2017 berjumlah 36,7 juta (World Health Organization, 2017). Sejarah tentang HIV/AIDS dimulai ketika tahun 1979 di amerika serikat ditemukan seorang gay muda dengan Pneumocystis Carinii dan dua orang gay muda dengan Sarcoma Kaposi (Katiandagho, 2015).

Data dari Direktorat Jendral Pencegahan dan Pengendalian Penyakit sampai tahun 2017, tercatat jumlah pederita HIV sebanyak 14.640 
penderita dan jumlah penyakit AIDS sebanyak 4.725 orang.

Jumlah kasus baru HIV/AIDS sampai pada bulan april 2017 berjumlah 10.376 dan menurut faktor risiko LSL (Lelaki Seksual Lelaki) atau gay berjumlah 2.867 orang (Kementrian Kesehatan RI Direktorat Jenderal Pencegahan dan Pengendalian Penyakit, 2017). Berdasarkan data Provinsi Sulawesi Utara penderita HIV/AIDS berjumlah 2.382 kasus dimana untuk kasus HIV sebanyak 742 kasus dan kasus AIDS sebanyak 1.642 kasus. Di Kota Manado penderita HIV/AIDS berjumlah 248 penderita (Dinas Kesehatan Provinsi Sulawesi Utara, 2017).

Salah satu tempat perkumpulan komunitas gay adalah Kawasan Marina Plaza dengan anggota berjumlah 85 orang, jumlah kasus positif HIV pada gay di tahun 2018 berjumlah 62 orang (VCT Puskesmas Tikala Baru, 2018). Berdasarkan latar belakang di atas dan melihat data yang diperoleh tentang HIV pada gay yang termasuk salah satu kelompok berisiko, maka penulis tertarik untuk meneliti tentang identifikasi HIV pada komunitas gay yang berada di kawasan Marina Plaza.

HIV (Human Imunodefisiensi Virus) adalah virus yang dapat menyebabkan AIDS dengan cara menyerang sel darah putih yang bernama sel CD4 (Cluster Of Differentiation 4) sehingga dapat merusak sistem kekebalan tubuh manusia. Setelah beberapa tahun jumlah virus semakin banyak sehingga sistem kekebalan tubuh tidak lagi mampu melawan penyakit yang masuk. Virus HIV menyerang sel CD4 dan merubahnya menjadi tempat berkembang biak virus HIV baru kemudian merusaknya sehingga tidak dapat digunakan lagi. Sel darah putih sangat di perlukan untuk sistem kekebalan tubuh. Tanpa kekebalan tubuh maka ketika diserang penyakit maka tubuh kita tidak memiliki pelindung (Hasdianah, Prima D, 2014).

Sel limposit adalah sel yang berperan dalam sistem kekebalan tubuh, maka pada orang dengan HIV sistem kekebalan tubuhnya akan menurun dan tidak mampu melawan segala penyakit yang datang. Namun demikian orang yang tertular HIV tidak berarti langsung langsung jatuh sakit, seseorang bisa hidup dengan HIV dalam tubuhnya selama bertahun- tahun tanpa merasa sakit atau mengalami gangguan kesehatan yang serius (Kementerian Kesehatan RI Direktorat Jenderal Bina Gizi dan Kesehatan Ibu dan Anak, 2011).

Penyakit Menular Seksual atau PMS, adalah penyakit yang ditularkan melalui hubungan seks. Penyakit menular seksual akan lebih beresiko bila melakukan hubungan seksual berganti-ganti pasangan baik melalui vagina, oral maupun anal (Scorviani, Nugroho, 2012).

Pemeriksaan laboratorium untuk HIV yaitu dengan menggunakan 3 strategi dengan mendahului konseling pra test atau informasi singkat. Ketiga test tersebut dapat menggunakan RDT (Rapid Diagnostic Test) metode ICT atau dengan ELISA. Antibodi biasanya baru dapat terdeteksi dalam waktu 2 minggu sampai 3 bulan setelah terinfeksi HIV (Kementerian Kesehatan RI Direktorat Jendral Pengendalian Penyakit dan Penyehatan Lingkungan).

Pengobatan HIV tidak di lakukan dengan standar medis, tetapi dengan pengobatan alternatif atau pengobatan lainnya, dikarenakan sampai saat ini belum ada obat yang bisa menghilangkan HIV. Obat yang digunakan berfungsi untuk menahan perkembangbiakan virus HIV di dalam tubuh. Untuk menahan lajunya perkembangan virus HIV di dalam tubuh di perlukan obat antiretroviral (ARV) (Hasdianah, Prima, 2014).

Kementerian Kesehatan RI tahun 2014, penanggulangan HIV/AIDS di atur dalam PERMENKES Nomor 21 tahun 2013 (Kebijakan AIDS Indonesia, 2018). Upaya pelayanan kesehatan dalam rangka penanggulangan penyakit HIV/AIDS di samping ditujukan pada penanganan penderita yang ditemukan juga diarahkan pada pencegahan melalui penemuan penderita secara dini yang dilanjutkan dengan kegiatan konseling. Pengendalian penyebaran kasus HIV/AIDS difokuskan pada kelompok remaja. Upaya yang dilakukan adalah melalui kampanye dan sosialisasi perilaku seksual yang harus dihindari sebelum ada komitmen yaitu pernikahan dan penyadaran tentang cara penularan penyakit HIV/AIDS (Masriadi, 2014). 
LSL (Lelaki Seksual Lelaki) atau gay adalah laki-laki yang dirinya sebagai biseksual atau homoseksual, yang telah berhubungan seks dengan laki-laki dalam satu tahun terakhir (Direktorat Jenderal Pengendalian Penyakit dan Penyehatan Lingkungan, 2011).

\section{METODE}

Jenis penelitian yang digunakan adalah penelitian Deskriptif, yaitu penelitian yang bertujuan untuk mengidentifikasi HIV (Human Immunodeficiency Virus) pada komunitas gay yang berada di Kawasan Marina Plaza Kota Manado menggunakan metode ICT Immunochromatography Test (ICT), yaitu metode pemeriksaan Rapid Diagnotic Test (RDT).

Jumlah populasi pada penelitian ini adalah 85 orang anggota komunitas LSL. Sampel pada penelitian ini yaitu seluruh komunitas gay di Kawasan Marina Plaza yang berjumlah 85 orang (total populasi). Data yang diperoleh dari hasil pemeriksaan HIV akan dianalisa secara deskriptif, disajikan dalam bentuk tabel dan narasikan.

\section{HASIL}

Kawasan Marina Plaza terletak di Kecamatan Wenang Kota Manado. Kawasan ini merupakan salah satu pusat perbelanjaan di Kota Manado. Di Kawasan ini terdapat tokotoko seperti toko pakaian, toko alat elektronik, toko alat rumah tangga. Di Kawasan ini tersedia juga tempat hiburan malam, bar, café, restoran dan rumah makan. Pada malam hari kawasan Marina Plaza menjadi salah satu tempat berkumpulnya komunitas gay yang cenderung melakukan hubungan seksual yang menyimpang dan dapat menjadi faktor resiko penularan HIV AIDS. Komunitas gay perlu mendapat perhatian dari pemerintah, dalam hal ini instansi kesehatan untuk mencegah atau mengurangi dampak negatif perilaku seksual menyimpang dari komunitas gay tersebut.

Puskesmas merupakan unit pelayanan teknis Dinas Kesehatan Kabupaten/Kota yang bertanggung jawab menyelenggarakan pembangunan Kesehatan disuatu wilayah kerja. Puskesmas Tikala Baru mempunyai 6 Kelurahan dimana jumlah penduduk 46.366 jiwa. Puskesmas Tikala Baru melaksanakan fungsinya dalam pelayanan kesehatan dengan menjalankan 14 Upaya Pokok Pelayanan Kesehatan sebagai berikut : 1) Upaya Pemeriksaan Umum, 2) Upaya Pelayanan Kesehatan Gigi dan Mulut, 3) Upaya Pelayanan Kesehatan KIA-KB, 4) Upaya Pelayanan Kesehatan Gawat Darurat, 5) Upaya Pelayanan Kesehatan Gizi, 6) Upaya Pelayanan Kesehatan Persalinan, 7) Upaya Pelayanan Kesehatan Kefarmasian, 8) Upaya Pelayanan Kesehatan Laboratorium, 9) Upaya Pelayanan Kesehatan Jiwa, 9) Upaya Pelayanan Kesehatan Gigi dan Masyarakat, 11) Upaya Pelayanan Kesehatan Olahraga, 12) Upaya Pelayanan Kesehatan Indra, 13) Upaya Pelayanan Kesehatan Lansia, 14) Upaya Pelayanan Kesehatan Kerja.

1. Distribusi Karakteristik Responden

Tabel 1. Dstribusi Responden Menurut Golongan Umur

\begin{tabular}{cccc}
\hline No & $\begin{array}{c}\text { Golongan } \\
\text { Umur }\end{array}$ & Jumlah & $\%$ \\
\hline 1 & $17-22$ & 18 & 21 \\
2 & $23-28$ & 31 & 36 \\
3 & $29-34$ & 4 & 4 \\
4 & $35-39$ & 7 & 8 \\
5 & $40-44$ & 24 & 28 \\
6 & $45-49$ & 0 & 0 \\
7 & $50-54$ & 3 & 3 \\
\hline & Total & 85 & 100 \\
\hline
\end{tabular}

Berdasarkan tabel 1 diatas menunjukan bahwa pada anggota komunitas gay yang berjumlah 85 responden terdapat 18 responden (21\%) dengan golongan umur 17-22 tahun, 31 responden $(36 \%)$ dengan golongan umur 2328 tahun, 4 responden (4\%) dengan golongan umur 29-34 tahun, 7 responden (8\%) dengan golongan umur 35-39 tahun, 24 responden (28\%) dengan golongan umur 40-44 tahun, 0 responden $(0 \%)$ dengan golongan umur 45-49 tahun, dan 3 responden ( $3 \%$ ) dengan golongan umur 50-54 tahun.

Tabel 2. Distribusi Responden Menurut Jenis Pekerjaan

\begin{tabular}{clcc}
\hline No & \multicolumn{1}{c}{ Pekerjaan } & Jumlah & $\%$ \\
\hline 1 & Belum Bekerja & 14 & 16 \\
2 & Mahasiswa & 5 & 6 \\
3 & Karyawan & 66 & 78 \\
& Swasta & & \\
\hline$\quad$ Total & 85 & 100 \\
\hline
\end{tabular}


Berdasarkan tabel 2 diatas menunjukan bahwa pada anggota komunitas gay yang berjumlah 85 responden terdapat 14 responden $(16 \%)$ yang belum bekerja, 5 responden (13\%) mahasiswa, 66 responden (78\%) karyawan swasta.

Tabel 3. Distribusi Responden Menurut Tingkat Pendidikan

\begin{tabular}{cccc}
\hline No & Pendidikan & Jumlah & $\%$ \\
\hline 1 & SMA & 75 & 88 \\
2 & D3 & 4 & 5 \\
3 & S1 & 6 & 7 \\
\hline & Total & 85 & 100 \\
\hline
\end{tabular}

Berdasarkan tabel 3 diatas menunjukan bahwa pada anggota komunitas gay yang berjumlah 85 responden terdapat 75 responden (88\%) SMA, 4 responden (5\%) D3, 6 responden responden (7\%) $\mathrm{S} 1$.

2. Hasil Pemeriksaan Sampel Darah

Respondem

Tabel 4. Hasil Identifikasi HIV Pada

Responden

\begin{tabular}{cccc}
\hline No & HIV & Jumlah & $\%$ \\
\hline 1 & Positif & 1 & 1 \\
2 & Negatif & 84 & 99 \\
\hline & Total & 85 & 100 \\
\hline
\end{tabular}

Berdasarkan tabel 4 diatas menunjukan bahwa pada anggota komunitas gay yang berjumlah 85 responden terdapat 1 responden (1\%) positif HIV dan 84 responden (99\%) negatif HIV.

\section{PEMBAHASAN}

Pengambilan sampel darah dilaksanakan di Kawasan Marina Plaza dimana peneliti didampingi oleh petugas lapangan Klinik VCT Puskesmas Tikala Baru. Setelah pengambilan darah dilakukan, sampel darah langsung diperiksa di tempat pemeriksaan dengan menggunakan RDT (Rapid Diagnotic Test) metode ICT (Immunochromatography Test).

Tabel 1 menunjukan 18 responden (21\%) dengan golongan umur 17-22 tahun, 31 responden $(36 \%)$ dengan golongan umur 2328 tahun, 4 responden (4\%) dengan golongan umur 29-34 tahun, 7 responden (8\%) dengan golongan umur 35-39 tahun, 24 responden
(29\%) dengan golongan umur 40-44 tahun, tidak ada responden (0\%) dengan golongan umur 45-49 tahun, 3 responden (3\%) dengan golongan umur 50-54 tahun, sedangkan persentasi kasus HIV/AIDS tertinggi berdasarkan kelompok umur yaitu 30-39 tahun (Kementerian Kesehatan Republik Indonesia, 2009)

Tabel 2 menunjukkan bahwa 14 responden (16\%) yang belum berkerja, 5 responden $(6 \%)$ mahasiswa, dan 66 responden $(78 \%)$ karyawan swasta. Kelompok kasus faktor resiko sebagian besar yaitu kelompok resiko yang mempunyai pekerjaan namun memiliki penghasilan yang kurang (Gunawan dkk, 2016).

Tabel 3 menunjukan bahwa 75 responden (88\%) SMA, 4 responden $(5 \%)$ D3, dan 6 responden $(7 \%)$ S1. Pada penelitian yang dilakukan oleh Oktarina (2009) tentang Hubungan Antara Karakteristik Responden, Keadaan Wilayah dengan Pengetahuan, sikap terhadap HIV/AIDS menjelaskan bahwa pengetahuan dan sikap seseorang dipengaruhi oleh latar belakangnya.

Tabel 4 menunjukan bahwa 1 responden (1\%) dengan hasil positif HIV. Responden yang positif HIV berumur 25 tahun dengan pekerjaan sebagai karyawan swasta. Responden menjadi komunitas LSL sudah 6 tahun dan pernah melakukan hubungan seks dengan pria dengan cara anal dan oral.

AIDS disebabkan oleh virus yang mempunyai beberapa nama yaitu HTL II, LAV, RAV, yang nama ilmiahnya disebut Human Immunodeficiency Virus (HIV)yang ditularkan oleh darah dan punya afinitas yang kuat terhasap limfosit T. Human Immunodeficiency Virus (HIV) menginfeksi sel lewat pengikat dengan protein perifer CD 4 (Scorviani, Nugroho, 2012). Infeksi virus ini mengakibatkan terjadinya penurunan system kekebalan tubuh yang terus menurus (Lembaga Kesehatan Nahdlatul Ulama, 2013).

Rentang waktu sejak virus HIV masuk kedalam tubuh sampai pada antibodi menjadi positif disebut window period. Lama window period antara 15 hari - 3 bulan bahkan ada yang $1-6$ bulan pada fase ini umumnya orang yang terinfeksi HIV masih tampak dan merasa sehat, sebagaimana yang telah dipahami 
bahwa tanpa sistem kekebalan tubuh yang baik maka seseorang akan mudah terserang berbagai penyakit. Masa tanpa gejala terjadi selama kurang lebih $10-15$ tahun, Seorang penderita dapat bertahan hidup selama $1-2$ tahun, selanjutnya penderita AIDS akan meninggal karena komplikasi penyakit yang dideritanya (Katiandagho, 2015)

Menurut karakteristiknya ada beberapa faktor yang mempengaruhi penularan HIV yaitu umur, pekerjaan, dan pendidikan (Fitryani, 2015). Berdasarkan penelitian yang dilakukan Kambu, dkk, (2016) dimana hasil penelitian menunjukan bahwa umur merupakan factor yang paling mempengaruhi penularan HIV karena umur yang masih muda lebih beresiko menularkan HIV karena disebabkan pada umur tersebut cenderung melakukan hubungan seks yang tidak aman. Menurut Umam Husnul (2015) bahwa hubungan penularan HIV dengan pendidikan seseorang sangat berpengaruh, karena orang dengan jenjang pendidikan yang lebih tinggi biasanya memiliki tingkat pengetahuan yang baik, namun hasil penelitian ini menunjukan bahwa responden yang berpendidikan tinggi justru melakukan tindakan yang beresiko tertular HIV, hal ini menunjukan bahwa semakin tinggi tingkat pendidikan maka akan cenderung melakukan tindakan beresiko tertular HIV, maka dapat disimpulkan bahwa pendidikan dalam penelitian ini tidak berpengaruh terhadap penularan HIV. Pada penelitian yang dilakukan oleh Prabowo, dkk (2017) dijelaskan bahwa tidak adanya hubungan antara penularan HIV dengan kategori umur dan jenis pekerjaan seseorang, dimana kategori umur 21-30 dan bekerja sebagai karyawan merupakan pengidap HIV.

Berdasarkan factor umur, data yang diperoleh menunjukan bahwa rata-rata lama responden menjadi anggota komunitas LSL sejak responden lulus dari Sekolah Menengah Atas. Hasil penelitian ini didukung penelitian sebelumnya yang dilakukan oleh Fauziah, dkk (2018) yang menjelaskan bahwa usia 18 tahun adalah kategori usia remaja, dimana keinginan untuk mencari jati diri semakin bebas dengan adanya rasa keinginan dan ketertarikan pada sejenis, perasaan cinta, dan hal-hal yang ingin dicoba demi mendapatkan pengalaman yang baru.

Berdasarkan penelitan Paryati, dkk
(2010) mengatakan bahwa orang tua mempunyai peran untuk mengajarkan pendidikan seks kepada anak. Keluarga yang broken home menjadi faktor yang sangat berpengaruh terhadap pendidikan seks pada anak. Perilaku homoseksual dapat diawali pada masa kanak-kanak yang disebabkan oleh gangguan perkembangan seksual dan ditambah dengan hubungan keluarga yang tidak harmonis. Faktor lingkungan juga sangat berpengaruh untuk seseorang berperilaku homoseksual misalnya tempat tinggal, pergaulan bebas, pengaruh teman, dan sering bergabung dalam kelompok atau komunitas tertentu yang cenderung menyimpang.

\section{KESIMPULAN}

Hasil penelitian menunjukan bahwa, dari 85 responden terdapat 1 responden $(1 \%)$ yang positif HIV dan 84 responden (99\%) yang negative HIV.

\section{SARAN}

Kepada anggota komunitas LSL yang terinfeksi HIV agar mengkonsumsi obat ARV (Anti Retroviral) secar rutin. Bagi anggota komunitas LSL yang belum terinfeksi HIV agar dapat mencegah penularan dengan cara menggunakan kondom pada saat melakukan hubungan seks atau meninggalkan perilaku seksual yang menyimpang.

\section{UCAPAN TERIMA KASIH}

Ucapan terima kasih disampaikan kepada petugas klinik Puskesmas Tikala Baru yang telah membantu peneliti dalam pemeriksaan sampel darah responden.

\section{DAFTAR PUSTAKA}

1. Dinas Kesehatan Daerah Provinsi Sulawesi Utara, 2017, Profil Kesehatan Provinsi Sulawesi Utara 2016,dinkes.sulutprov.-go.id/wp content/uploads/2016/11/Buku-Profil Kesehatan Sulut 2016.pdf, 24 November 2018. 
2. Direktorat Jenderal Pencegahan dan Pengendalian Penyakit, 2017, laporan Situasi Perkembangan HIV-AIDS dan PIMS Di Indonesia Januari-maret 2017, siha.depkes.go.id/portal/files/_uploads/lap oran_HIV_AIDS_Tw_1_2017_rev.pdf, 24 November 2018.

3. Direktorat Jenderal Pencegahan dan Pengendalian Penyakit, 2018, Laporan Perkembangan HIV-AIDS \& IMS Triwulan IV tahun 2017, siha.depkes.go.id/portal/-

files_upload/laporan HIV AIDS TW 4 Tahun 2017 1_pdf, 15 Januari 2019.

4. Direktorat Jenderal Pengendalian Penyakit dan Penyehatan Lingkungan, 2011, Survailans Terpadu Biologis Perilaku, kpakotabandung.or.id/book/Survailans Terpadu Biologis Dan Perilaku 2011.pdf, 28 Januari 2019.

5. Fauziah, Zahron Shaluhiyah, Priadi Nugraha, 2018, Respon Remaja Lelaki Suka lelaki (LSL) dengan status HIV Positif Terhadap Pencegahan Penularan HIV Kepada Pasangan, Jurnal Promosi Kesehatan Indonesia, Volume 13, No. 1

6. Hasdianah, Prima dewi, 2014, Virologi Mengenal Virus Penyakit dan Pencegahan, Nuha Medika, Yogjakarta.

7. Katiandagho Desmon, 2015, Epidemiologi HIV/AIDS, In Media, Bogor.

8. Kementerian Kesehatan RI, 2011, Modul Pelatihan Pelayanan Kesehatan Peduli Remaja (PKPR) Bagi Tenaga Kesehatan, Kementerian Kesehatan RI, Jakarta.

9. Masriadi, 2017, Epidemiologi Penyakit Menular, Raja Grafindo, Depok.
10. Menteri Kesehatan Republik Indonesia, 2013, Kebijakan AIDS Indonesia, https://www.kebijakanaidsindonesia.net/id /dokumen-kebijakan/download17 Peraturan Pusat National Regulation/361Permenkes RI No. 21 Tahun 13 Tentang Penanggulangan HIV Dan AIDS, 25 November 2018.

11. Miftah Fagih, Sri Rahayu, Sarmidi Husna, Mahbub Ma'afi, 2013, Panduan Penanggulangan AIDS Perspektif Nahdlatul Ulama, Lembaga Kesehatan Nahdlatul Ulama, Jakarta.

12. Oktarina, Fachrudi Hanafi, Made Asri Budisuari, 2009, Hubungan Antara Karakteristik Responden, Sikap Terhadap HIV/AIDS Pada Masyarakat Indonesia, Jurnal Penelitian Sistem Kesehatan, Volume 12, Nomor 4.

13. Said Firdaus, Helfi Agustin, 2013, Faktor Resiko Kejadian HIV Pada Komunitas LSL (Lelaki Seks Dengan Lelaki) Mitra Yayasan Lentera Minangkaban Sumatra Barat, Jurnal Kesehatan Komunitas, Volume 2, Nomor 2.

14. Verra Scorviani, Taufan Nugroho, 2012, Mengupas Tuntas 9 Jenis PMS (Penyakit Menular Seksual), Nuha Medika, Yogjakarta.

15. World Health Organization, 2017, HIV/AIDS, www.who.int/features/qa/71/en/, 24 November 2018.

16. Yoel Kambu, Agung Waluyo, Kuntarti, 2016, Umur Orang Dengan HIV/AIDS (ODHA) Berhubungan Dengan Tindakan Pencegahan Penularan HIV, Jurnal Keperawatan Indonesia, Volume 19, Nomor 3. 